\title{
Early Childhood Education in Saudi Arabia: Report
}

\author{
Alqassem Rabaah ${ }^{1, *}$, Dashash Doaa ${ }^{1} \&$ Alzahrani Asma $^{1}$ \\ ${ }^{1}$ Education College and Human Development, George Mason University, Fairfax, VA, USA \\ *Correspondence: Education College and Human Development, George Mason University, Fairfax, VA, USA. Tel: \\ 571-278-119. E-mail: rabaahalqassem@gmail.com
}

Received: August 24, 2016

Accepted: September 2, $2016 \quad$ Online Published: September 22, 2016

doi:10.5430/wje.v6n5p1

URL: http://dx.doi.org/10.5430/wje.v6n5p1

\begin{abstract}
This paper reviewed the development of early childhood education (ECE) in Saudi Arabia and its strengths and weaknesses. The paper discusses the contextual background of Saudi Arabia, including its geography, demographics, social system, economy, political system and religion. In addition, the paper investigated the education system at large in Saudi Arabia, including its development, objectives, enrollment and challenges.
\end{abstract}

Keywords: Saudi Arabian early childhood education; Saudi Arabian education system; Saudi Arabia education challenges; early childhood Saudi curriculum; early childhood Saudi teacher preparation

\section{Introduction and the Purpose of the Paper}

Early childhood education is a fundamental component of the education system in Saudi Arabia. The idea of kindergarten education in Saudi Arabia was introduced in 1974 with the establishment of preschool and kindergarten classes in 1975 (Aljabreen and Lash, 2016). A successful governmental pre-kindergarten and kindergarten in Makkah consisting of ten classrooms and seventeen workers, of which fourteen were teachers, led to formal introduction of pre-kindergarten and kindergarten into the countrywide school program. These numbers increased to 182,556 students, 22,189 teachers, and 2,559 schools in 2013-2014 (King Khalid Database, 2015). These numbers underscore the importance that Saudi parents attach to early childhood education and its role in the overall education program of Saudi children.

The purpose of this paper is to discuss the importance of early childhood education in Saudi Arabia - its strengths and weaknesses and how it can be expanded and the quality improved in order to benefit all children of Saudi Arabia. To explore the subject in depth, this paper will first discuss the contextual background of Saudi Arabia, including its geography, demographics, social system, economy, political system and religion. Then, the paper will explain the education system at large in Saudi Arabia, including its development, objectives, enrollment and challenges. Finally, there will be information on Saudi Arabia's early childhood education programs, including access and the various programs offered

\subsection{Geography}

Saudi Arabia is a large country that takes up four-fifths of the Arabian Peninsula, covering 2,150,000 square kilometers of land. Saudi Arabia is surrounded by the Red Sea, Jordan, Iraq, Kuwait, the Arabian Gulf, Bahrain, Qatar, the United Arab Emirates, Oman, and Yemen (Ministry of Foreign Affairs, 2016). The landscape of Saudi Arabia is very diverse due to its large size, and the landscape includes deserts, grasslands, mountains, forests, and coastline near the sea. Saudi Arabia experiences two seasons: winter and summer. In the winter, it is very cold; temperatures in the north and central parts of the country can drop below freezing. In the summer, it can reach over 110 degrees Fahrenheit, and rain is scarce (Ministry of Foreign Affairs, 2016).

Saudi Arabia's education system schedules the school day in response to the climate (Algamdi \& Nooraldeen, 2002). Due to the fact that temperatures climb during the middle of the day and early afternoon, many Saudi Arabian schools begin early so they can let out before the extreme heat begins.

\subsection{Demography}

Saudi Arabia's 2010 census recorded about 29,195,895 million people, a majority of which are young adults 
(Ministry of Foreign Affairs, 2016). In fact, 67.1\% of the population is under 30 years old (Oxford Business Group, 2007). At the end of 2015 the General Authority for Statistics Kingdom of Saudi Arabia reported a population of about 31,015,999 with a growth rate of 2.11\% (General Authority for Statistics, 2016).

The predominant and official language of Saudi Arabia is Arabic. According to Algamdi \& Nooraldeen (2002), the national education system in Saudi Arabia works hard to prioritize teaching Arabic in every grade. The Saudi Arabian education system also tries to improve students' Arabic across the curriculum because it is the official language of the country.

\subsection{Social System}

There have been many social changes that have shaped the social structure in Saudi Arabia. According to Gahwaji (2013), "The rise of individual/family incomes has affected the lifestyle of many Saudi families, particularly the middle and upper classes” (p. 336). One component that led to this rise in family incomes is the growing trend of Saudi Arabians working. Once the education system allowed women in the country to be educated, they began to enter the workforce. Because of this increase in women working, many families need someone to watch their children, and this has boosted the need for nannies and caregivers. Many of the maids, nannies and caregivers employed in Saudi Arabia are from foreign countries, such as the Philippines, Indonesia, India and Ethiopia.

The growth in income and the rise of women working has also changed the family dynamic: there is a move toward only nuclear families living together, versus an extended family structure cohabitating. According to Al-Sunbul, Al-Khateeb, Metwali, and Nour-Deen (2004), families in Saudi Arabia are growing smaller and becoming independent, distancing themselves from their broader extended family network. Smaller families and a growing female presence in the workplace has impacted childhood education policy and opportunity because children are more likely to be placed in child care and education programs or preschool centers (Gahwaji, 2013).

\subsection{Economy}

The predominant industry in Saudi Arabia is oil, which has transformed the nation's economy. Oil revenues allowed for rapid development in different aspects of daily life, and social changes followed economic growth (Gahwaji, 2013). According to the Ministry of Foreign Affairs (2010), Saudi Arabia has a free market economy, with the private sector accounting for $25 \%$ of the country's GDP. However, the government plays a large role in the country's economic system, where they create economic and social development plans and oversee individual industry's ministries (Ministry of Foreign Affairs, 2010).

Just as women entering the workforce impacted Saudi Arabia's social structure, it also impacted the economic system. According to Gahwaji (2013), an additional reason why many women in Saudi Arabia must work is because of changes in their lifestyle and the cost of a household, which have pushed women to earn an income. Higher instances of divorce and women being widowed are other economic motivators for women to enter the workplace, leading to more children being placed in the education system and increasing its significance in Saudi society.

The economic system in Saudi Arabia supports a large investment in education. Because of the country's wealth, it is able to invest more into their national education system. This can be seen in the amount the country spends in each year's budget on education expenses, including books, infrastructure and programs, as well as teacher salaries, which are high when compared to other countries like the United States. According to the U. S. - Saudi Arabian Business Council (2015), the Saudi Arabian government spent \$56 billion on education in 2014.

\subsection{Political System}

The current political system in Saudi Arabia was established in 1932 by the late King Abdul-Aziz bin Abdul-Rahman Al Saud (Ministry of Foreign Affairs, 2013). The political system is a hereditary monarchy that is run by the king. According to the Ministry of Foreign Affairs (2013), the king acts as the Prime Minister, Chief of State, and the head of government in Saudi Arabia. The crown prince is second in line to the throne, and the king appoints a crown prince to help him with his duties. The current king is very supportive of education and allows the government to invest heavily in education. Members of the Council of Ministers also assist the king in the performance of his duties. The Council of Ministers, also called the Cabinet, is comprised of 22 government ministries. These ministries specialize in different aspects of the government, such as foreign affairs, education and finance. This means that there is an entire ministry devoted to promoting the interests and needs of educators and students. There are no elections for political offices in Saudi Arabia, as it is a monarchy.

\subsection{Religion and Philosophy}

In order to fully understand Saudi Arabian education, it is important to acknowledge how deeply the national religion 
of Islam is embedded in the culture and social structure. The Quran is the holy book of Islam, and the religion's holy city, Mecca, is located in Saudi Arabia. According to Prokop (2003), Islam continues to be the main legitimating source for the al-Saud family, and religious education is emphasized at all levels in Saudi Arabia.

According to the Educational policy in Saudi Arabia, the objectives of education are as follows: understanding Islam correctly and completely, implanting and spreading the Islamic doctrine, providing students with Islamic values and instructions, acquiring knowledge along with different skills, developing constructive behavioral tendencies; advancing society economically, socially, culturally, and enabling students to become useful in the construction of their society (Educational policy article 28, Ministry of Education, 1976, cited in Gahwaji, 2013, p. 335).

The government has made concessions to the religious authorities in the fields of culture, curriculum development, and control over the educational apparatus. For example, the way history is taught in Saudi schools reflects the government's aim of unifying the population and creating a common Saudi identity. The government is becoming more aware of the effects of what is taught in Saudi schools. Thus, the government works to remove what it deems to be objectionable messages. It also makes attempts to change teaching methods, introduce modern technology, reduce rote learning, and encourage analytical thinking. Therefore, the Saudi foreign minister concluded that the education system in Saudi Arabia could not be considered a breeder of terrorism. Indeed, Saudi educational policy holds their students to the following criteria: "1) Representing praiseworthy Islamic morals in oneself and with others, 2) positive interaction with other cultures, 3) and wise and honest interaction with others” (Alshaer, 2008, p. 4).

Many of the educational goals in Saudi Arabia are based on the words of the Quran and the Sunnah, the writings of the prophet Mohammad (Al-Sunbul et al., 2004). Another important component of Islam that is embedded in the Saudi Arabian education system is the idea that there should be equal opportunity in life for both genders. This has led to strong social support for women's education since the 1960s, when education became a national priority (Gahwaji, 2013).

\subsection{Education System}

Springsteen (2014) indicates that the education system in Saudi Arabia formally began in 1932. By 1945, the country's founder, King Abdul-Aziz bins Abdulrahman Al-Saud, mandated the government to establish schools in the kingdom. At that time, education was available to very few people, mainly the male children of wealthy families. Education was available only for boys; it was nonexistent for girls until 1964, when the first school for girls was built. By the end of the 1990s, girls' schools had been established in every part of the kingdom. Now, girls' schools exist around the country, and schools continue to be segregated by gender (Springsteen, 2014). The separation of the genders in schools is a social and religious issue, as the teachings of Islam mandate that the genders be separated in environments like schools (Alromi, 2000, p. 10). In all Saudi schools, for girls and boys, educational policy is implemented to ensure that education becomes more efficient to meet the religious, economic and social needs of the country and to eradicate illiteracy among Saudi adults (Saudi Arabian Cultural Mission, 2013).

The Ministry of Education sets overall standards for Saudi Arabia's educational system - public and private - and also oversees special education (Saudi Arabian Cultural Mission, 2013). They provide schools for blind, deaf, and developmentally disabled students, as well as those needing physical therapy and training. Almost $96 \%$ of students with multiple and severe disabilities, such as those with severe autism, are currently taught in private special education institutions. Students with mild and moderate cognitive disabilities receive their education in an inclusive setting in public schools (Alquraini, 2010).

In addition, the U. S. - Saudi Arabian Business Council (2009) illustrates that the education system in Saudi Arabia can be divided into two broad categories: general education and higher education. All public and private schools follow the same general policies, curricula, and methods of instruction. The curriculum has a heavy emphasis on Arabic and Islamic studies, but other subjects, such as math, history, and geography, are also taught along with English. General education consists of:

- Pre-primary education

\section{o Duration (ages 3 to 5)}

- In 2008, the total enrollment ratio was estimated around $11 \%$. In 2009/10, 106,301 children were enrolled within a total of 1,521 kindergartens (UNESCO, 2010-2011).

- Primary School

o Duration: Six years (ages 6 to 12 ) 
- In 2009/10, the total enrollment in all primary schools was 2,493,125 students. From that total, 1,227,699 were girls (UNESCO, 2010-2011).

- Intermediate School

o Duration: Three years (ages 12 to 15 )

- In 2009/10, there were a total of 1,188,342 students enrolled. Of that number, 553,415 were girls (UNESCO, 2010-2011).

- General Secondary School

o Duration: Three years (ages 15 to 18 )

- "In 2009/10, there were 4,909 secondary schools, of which 2,440 for girls and 2,469 for boys. The total enrollment was 1,096,174 students, of whom 490,122 were girls" (UNESCO, 2010-2011, P.12).

- University and college

o Duration: Four years (ages 19 to 22) (U. S. - Saudi Arabian Business Council, 2009).

- In 2015, there were one million students enrolled in Saudi universities and colleges, compared to only 7,000 in 1970 (Saudi Arabia Embassy, 2016).

“Today, Saudi Arabia's education system includes 25 publics and 27 private universities, with more planned; some 30,000 schools; and a large number of colleges and other institutions” (Saudi Arabia Embassy, 2016). The government grants monthly allowances of approximately $\$ 200$ for all university students as a way to incentivize people to get their undergraduate degrees. The U. S. - Saudi Arabian Business Council (2009) indicates that the system is open to all citizens and provides free education in all phases in public institutions, including higher education, to all residents and citizens. The state provides books and educational means. It also prepares, trains, and qualifies teachers, pays salaries, promotes teachers, dispatches internal and external exchange students, organizes cultural exchanges with other countries, and defines the quality of education. In addition, the state encourages its young Saudi population to continue their education internationally, in nations all around the world, by providing free scholarships. This is done to allow Saudi students to gain new experiences and learn about new ideas that they can use when they return to Saudi Arabia. Saudi Arabia is ranked first among Middle Eastern countries in the number of students studying in the U.S. (U. S. - Saudi Arabian Business Council, 2009).

\subsection{Challenges in the Education System}

Howell (2014) indicates that the most difficult of the domestic challenges facing Saudi Arabia lays in the shortcomings of its education system. According to Howell (2014), despite billions of dollars being invested, the quality of teachers remains problematic. Saudi nationals lose higher-paying job opportunities to better educated and more qualified foreign workers. Additionally, in the period between 2008 and 2012, Saudi Arabia had a very high literacy rate for people in the 15-24-year age group: 99\% for males and 97\% for females. Despite this high literacy rate, the lack of available jobs contributes to a general sense of disillusionment about obtaining an education. Also, the best schools in Saudi Arabia are private institutions that charge higher fees, leading to accusations against the government that only the rich can afford a quality education. Thus, the disparity in Saudi Arabia between the public and private sectors appears to be particularly pronounced. Public schools rely heavily on rote learning and memorization, and do not offer additional subjects such as theatre and art. By comparison, private schools favor a teaching style in which critical thinking is encouraged, and European and North American curricula are followed. These factors support the complaints of some Saudi citizens that they are educationally disadvantaged (Howell, 2014).

\section{Early Childhood Education in Saudi Arabia}

The Saudi Ministry of Education emerged during the establishment of the modern country. Girls' education started in Saudi Arabia in 1964 (Al-Otaibi \& Al- Swailm 2002). However, the idea of kindergarten had never been introduced before 1974. Consequently, the need for early childhood care and education programs increased, resulting in the establishment of the first preschool and kindergarten classes starting in 1975, with classes that were attached to general education schools (Aljabreen \& Lash, 2016).

Due to the success of the governmental pre-kindergarten and kindergarten program opened in Makkah with ten classrooms and seventeen workers in 1975, the government decided to improve the idea of kindergarten schools 
(Aljabreen \& Lash, 2016). As shown in Table 1, 19 pre-kindergarten and kindergarten schools were opened in 1980, and they were attended by 2,000 children and 166 teachers and other non-teaching staff. Moreover, in 2013-2014, the number of children at pre-kindergarten and kindergarten schools has increased to 182,556 with 22,189 teachers in 2559 schools that are supervised by different agents in the country (King Khalid Database, 2015).

Table 1. The Growth of Pre-Schools and Kindergartens in Saudi Arabia

\begin{tabular}{lllll}
\hline Year & Number of Pre-K/K & Number of kids & Number of teachers & Student: teacher \\
\hline 1975 & 1 & 200 & 14 & $14.3: 1$ \\
1980 & 19 & 2067 & 166 & $12.5: 1$ \\
$2013-2014$ & 2559 & 182,556 & 22,819 & $8: 1$ \\
\hline
\end{tabular}

According to the Alshehri (2014), there are 1,385 public pre-kindergarten and kindergarten schools administrated by the Ministry of Education. However, although the private sector runs only 942 schools, they have more classes as well as higher enrollment. In addition, the Ministry of Social Affairs has 232 schools, which means 2,559 pre-kindergarten and kindergarten schools in all Saudi Arabia (see Figure 1).

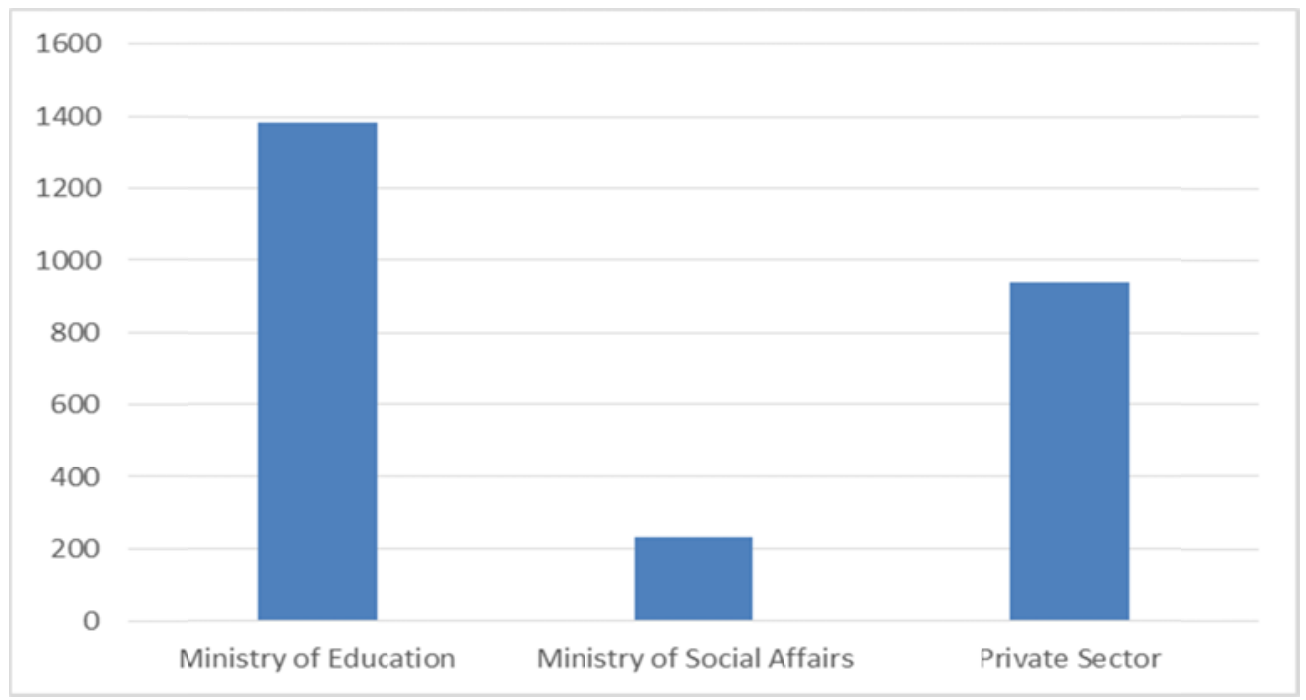

Figure 1. Number of Pre-Kindergarten and Kindergarten Schools in 2013-2014

According to Andrews and Slate (2002), the kindergarten education system is well known for lowering the cost of education since it dispenses programs and lessons, which relay and reduce the return-rate grade and reduce dropouts. Therefore, the 2015-2020 strategic plans of Saudi Arabia support increasing the number of pre-kindergarten and kindergarten schools with a goal of 300 schools a year and a total of 1500 schools in 5 years. However, the early childhood education enrollment ratio in Saudi Arabia, which is estimated between 10-12\%, is still considered very low when compared to other countries in world (Qasabi, 2012). Therefore, The Ministry of Budget has approved funds to seek increases in the number of kindergartens annually as well as providing funds for private sectors as well as loans with no interest in service of developing more pre-kindergarten and kindergarten schools. This operation works hand-in-hand with the five-year plan and the draft National Strategy for development of public education. In addition, it will support private-sector initiatives, which include the company for academic education services' initiative in cooperation with the Saudi Credit Bank to support investors by providing them with the necessary loans (Ministry of Education, 2015).

\subsection{Development of ECE Curriculum and Approaches}

The development of curriculum and approaches in early childhood education went through many stages. The first stage was the traditional approach taken in 1952, when early childhood education was comprised of independent, individual practices (Alomar, 2013). This method depends on its content across a range of books and courses such as reading, writing, mathematics and science. 
The second stage was the project approach, which began in 1975. This approach was not significantly different from the traditional approach, especially in focusing on the education of the child to read and write (Alomar, 2013).

Finally, the third stage was the implementation of the self-learning curriculum approach, which was introduced in 1986 (Alomar, 2013). Official efforts began with the General Presidency for Girls' Education, as well as the regional organization (AGFUND) and the international organization (UNESCO) (Alshaer, 2008). It is important to have an integrated and comprehensive source for kindergarten teachers in the kingdom because such a source contains a multitude of technical information that helps teachers take into account the growth of the phase characteristics and needs. The three stages represent the pedagogical movement from teacher-centered towards learner-centered frameworks.

The kindergarten self-learning advanced curriculum is made of different educational units such as the water, the sands, my health and safety, and so on. Each unit lasts 2-4 weeks and presents theme-related experiences throughout the daily schedule. The schedule components include circle time, play-based centers, indoor or outdoor playing, and snack time. Features of the self-learning advanced curriculum include the following:

- Activity self-adopted curriculum expertise, designed to move and play, offering freedom and independence, research and discovery, to achieve the principle of learning to learn.

- Activity self-centered approach, where the child is heading the learning process of the child inside to the outside, to be achieved using interaction between the four elements of the child, the direct and indirect experience, and the environment.

- A comprehensive and balanced approach, which offers activities to meet the needs of the child's physical, mental, and social mobility in the context of integration and interdependence to achieve the unity of knowledge and balance performance (Alomar, 2013).

\subsection{ECE Goals in Saudi Arabia}

Saudi Arabia is governed by a number of policies regarding education, which include aims for Early Childhood Education. Additionally, such goals aim to expose children to the school atmosphere rather than only experiencing the conditions within the home compound (Aljabreen \& Lash, 2016; Ministry of Education, 2004). Schools are typically identified as one of the best areas where children can grow with very high discipline and rigor, hence preparing them for life. School environments also drive children to form relations with social peers.

\subsection{Curriculums of ECE Programs}

A timetable and program were developed to support the development of curriculum, which could affect the gradual expansion of education for the better in the establishment of kindergarten over the private home. To achieve these goals, construction of classrooms and effective curriculum for kindergarten was necessary to provide maximum learning. The early childhood education curriculum was featured prominently in a Royal Decree, which was introduced in 1988 with the cooperation of the General Presidency for Girls' Education, which is the highest authority that supervises women's education in Saudi Arabia, the Arab Gulf Program for United Nations Development Organization (AGFUND), and the United Nations Educational, Scientific and Cultural Organization (UNESCO), regarding concerted efforts to promote childhood through the preparation of curriculum for kindergarten and all materials required for teaching aids (Alshaer, 2008). Development of the kindergarten curriculum was accompanied by the establishment of four centers for the training of the national cadres.

\subsection{Special Education Services for ECE}

Special education in Saudi Arabia started through individual efforts. Communities cooperated and came up with the idea that children with disabilities should also engage in studies, since it is the right of each child to have education. This led to the construction of schools for such children. The education integration efforts in the kingdom of Saudi Arabia involved either the total integration method or partial integration. Total integration was achieved through the introduction of special education classes attached to regular school programs. It was carried out through the use of modern educational methods such as resource room programs, counselor and teacher programs, and follow-up programs in special education. (Hamdan, 2005)

\subsection{ECE Teacher Preparation and Professional Development}

Several studies propose that pre-kindergarten and kindergarten teachers who hold a degree or equivalent in early childhood education are more involved with kids as well as more knowledgeable when compared with those who does not have such credentials (Sylva et al., 2003). 
Through the years, early childhood education preparation transformed from teacher education institutes to the universities that prepare general pre-school teachers as well as special education teachers. According to the Saudi Al-Jadidi (2012), seventeen of the twenty-four public universities offer bachelor degrees in early childhood education, which takes care of preparing early childhood education teachers. However, there are at least four training centers attached to and administered by the Ministry of Education for the purpose of in-service teaching. These centers offer continuous early childhood professional development programs for teachers.

\section{Conclusion}

This paper reviewed the development of early childhood education (ECE) in Saudi Arabia and its strengths and weaknesses. The paper concludes that since its introduction, ECE in Saudi Arabia has grown dramatically in terms of student enrollment and governmental support as well as in quality as it shifts from rote, teacher-centered learning to independent student-centered learning with a more nuanced curriculum. The Saudi government continues to invest in education by increasing funding for school development as well as by investing specifically in teacher training and education with a clear belief that ECE is crucial to the country's educational objectives.

However, there is a lack of updated information about early childhood education in Saudi Arabia. The most recent statistics found were for the 2013-14 school year, which do not provide researchers with the most recent information. In addition, there are few studies that have looked at the ECE in KSA, and most are conducted in the Arabic language, making international comparisons difficult. Over the course of preparing this report, it was difficult to find up-to-date statistics and references that were relevant and appropriate. More research needs to be done in the future on ECE in Saudi Arabia to provide information for researchers and teachers.

\section{References}

Al Omar, M. (2013). Preschools: Impacts on children personalities. Knowledge Journal, 218, 62-67.

Algamdi, H., \& Nooraldeen, A. (2002). The development of the education system in the Kingdom of Saudi Arabia. Riyadh: Arab Bureau of Education for the Gulf States.

Aljabreen, H., \& Lash, M. (2016). Preschool Education in Saudi Arabia: Past, Present, and Future. Childhood Education, 92(4), 311-319. http://dx.doi.org/10.1080/00094056.2016.1208011

Al-Jadidi, N. (2012). The professional preparation, knowledge and beliefs of kindergarten teachers in Saudi Arabia (Order No. U590160). Available from ProQuest Dissertations \& Theses Global. (1414975289). Retrieved from http://search.proquest.com.mutex.gmu.edu/docview/1414975289?accountid=14541

Al-Otaibi, M. M., \& Al-Swailm, B. H. (2002). The analysis of early childhood education objectives in Saudi Arabia. The Scientific Islamic Research Journal, 24, 14-23.

Alquraini, T. (2011). Special Education in Saudi Arabia: Challenges, Perspectives, Future Possibilities. International Journal of Special Education, 26(2), 149-159.

Alromi, N. (2000). Vocational Education in Saudi Arabia. State College, PA: Penn State University.

Alsalloom, H. I. (1991). History of Educational Movement in the Kingdom of Saudi Arabia. Washington D.C.: International Grafeix.

Alshaer, A. I. (2008). Education for all programmes in the Kingdom of Saudi Arabia. Paper commissioned for the EFA Global Monitoring Report 2008, Education for All by 2015: Will we make it?

Alshehri, M. (2014). Improving reading comprehension for Saudi Students by using the Reading Aloud Strategy (Master thesis). Retrieved from https://dspace.sunyconnect.suny.edu/bitstream/handle/1951/65437/Alshehri_Mohammed_Masters_December20 14.pdf? sequence $=1$

Al-Sunbul, A., Al-Khateeb, M., Metwali, M., \& Nour-Deen, M. (2004). Educational System in Saudi Arabia. Riyadh: Al-Kheraiji for Publishing and Distribution.

Andrews, S. P., \& Slate, J. R. (2002). Public \& private Pre-Kindergarten programs: A comparison of student readiness. Educational Research Quarterly, 25(3), 59.

Gahwaji, N. M. (2013). Controversial and challenging concerns regarding status of Saudi preschool teachers. Contemporary Issues in Education Research, 6(3), 333-344. http://dx.doi.org/10.19030/cier.v6i3.7905 
General Authority for Statistics kingdom of Saudi Arabia. (2016). Important indicators. Retrieved from http://www.stats.gov.sa/en/indicators

Hamdan, A. (2005). Women and education in Saudi Arabia: Challenges and achievements. International Education Journal, 6(1), 42-64.

Howell N. (2014). Difficult times ahead: The challenges facing Saudi Arabia. Retrieved from http://www.futuredirections.org.au/publications/indian-ocean/1825-difficult-times-ahead-the-challenges-facingsaudi-arabia.html

King Khalid Data Base (2015). Early childhood education in Saudi Arabia. Retrieved from http://www.kingkhalid.org.sa/Gallery/Text/ViewBooks.aspx?View=Page\&PageID=248\&BookID=7

Ministry of Education. (1976). Educational policy: Government Decree 89/A/23/03/76 (Riyadh, Ministry of Education).

Ministry of Education. (2002). The education committee of curriculum and supervision education: Government Decree 407/A/26/09/02, Riyadh, Ministry of Education.

Ministry of Education. (2004). The education committee of curriculum and supervision education: Government Decree 518/A/18/06/04, Riyadh, Ministry of Education.

Ministry of Education. (2008). Development of education in the Kingdom of Saudi Arabia. Riyadh, Saudi Arabia: Al-Frazdak Printing Press.

Ministry of Education. (2015). General management for kindergarten. Retrieved from http://www.moe.gov.sa/AR/MINISTRY/BOYSEDUCATIONAGENCY/KINDERGARTEN/Pages/default.aspx

Ministry of Foreign Affairs. (2010). Economy and resources. Retrieved from http://www.mofa.gov.sa/sites/mofaen/ServicesAndInformation/aboutKingDom/InvestmentAndTourism/Pages/A dvantagesofInvestmentinSaudiArabia34476.aspx

Ministry of Foreign Affairs. (2013). History of the kingdom. Retrieved from http://www.mofa.gov.sa/sites/mofaen/ServicesAndInformation/aboutKingDom/Pages/CountryDevelopment361 43.aspx

Ministry of Foreign Affairs. (2016). About Saudi Arabia. Retrieved from http://www.mofa.gov.sa/sites/mofaen/ServicesAndInformation/aboutKingDom/Pages/KingdomGeography4646 6.aspx

Oxford Business Group. (2007). The Report: Emerging Saudi Arabia 2007. London: Oxford Business Group.

Prokop, M. (2003). Saudi Arabia: The politics of education. International Affairs, 79(1), 77-89.

Qasabi, O. (2012). 90\% of first grade students did not enroll in kindergarten. Retrieved from www.alriyadh.com/766586

Saudi Arabia Embassy. (2016). Education. Retrieved from http://ksamissioneu.net/en/education/

Saudi Arabian Cultural Mission. (2013). Background educational system in Saudi Arabia. Retrieved from http://www.sacm.org/Education.aspx

Springsteen, S. Marie. (2014). Examining Student Motivation in Saudi Arabia. MA TESOL Thesis, SIT Graduate Institute. $\quad$ Retrieved

from http://digitalcollections.sit.edu/cgi/viewcontent.cgi?article=1703\&context=ipp_collection

Sylva, K., Melhuish, E., Sammons, P., Siraj-Blatchford, I., Taggart, B., \& Elliot, K. (2003). The effective provision of pre-school education (EPPE) project: Findings from the pre-school period (summary). London: University of London Institute of Education, DfES/Sure Start.

U. S.-Saudi Arabian Business Council. (2009). The Education Sector in the Kingdom of Saudi Arabia. Retrieved from https://www.us-sabc.org/files/public/Education_Brochure.pdf

U. S.-Saudi Arabian Business Council. (2015). Saudi Arabia’s 2014 budget emphasizes long-term development. Retrieved from http://www.us-sabc.org/custom/news/details.cfm?id=1541

UNESCO. (2010/2011). International Bureau of Education. "Saudi Arabia" World Data on Education (7th ed.). Retrieved http://www.ibe.unesco.org/fileadmin/user_upload/Publications/WDE/2010/pdf-versions/Saudi_Arabia.pdf 